\title{
Textile depilling: Superior finishing using cellulose-binding domains with residual enzymatic activity
}

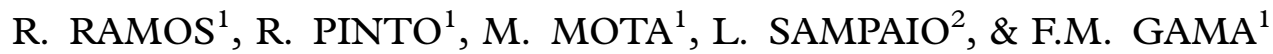 \\ ${ }^{1}$ Centro de Engenharia Biológica, Campus de Gualtar, Universidade do Minho, 4710-057 Braga, Portugal, and ${ }^{2}$ Tinturaria \\ e Acabamentos Tecidos Vale de Tábuas, Lda - R. da Cruzinha, 4780-000 Santo Tirso, Portugal
}

(Received 19 fanuary 2006; revised 13 April 2006)

\begin{abstract}
Textile fabric depilling is an important industrial application of cellulases. The depilling effect and achievement of desirable touch properties are among the applications sought by users. This process, although effective, is associated with significant tensile strength loss. The depilling mechanism is still a subject of controversy. In this work, we introduce a new perspective in understanding of the depilling mechanism, specifically we consider the contribution of interfacial properties. Cellulose Binding Domains (CBDs) obtained by ultrafiltration after digestion with a protease, were used in depilling experiments. Compared with cellulose, the performance of CBDs was very positive. In fact, when using CBD with residual hydrolytic activity, it was possible to achieve superior depilling treatments.
\end{abstract}

Keywords: Cellulose-Binding Domains, Depilling, interfacial properties, tensile strength

\section{Introduction}

Cellulases are increasingly being applied for textile finishing. They are widely used to remove fibrils and fuzz fibres from cotton fabrics, or to produce the 'stone-washed' look of denim garments. However, a major problem with cellulases is the subsequent loss in tensile strength. Lenting and Warmoeskerken (2001a) provided guidelines to prevent tensile strength loss. According to these authors, strength loss is caused by the degradation of crystalline cellulose.

Cellulases are produced by a wide variety of bacteria (e.g. Clostridium, Cellulomonas) and fungi (e.g. Humicola, Trichoderma, Penicillium). Among these, the more important commercially is that from Trichoderma reesei (Heikinheimo et al. 1998). The cellulolytic system is composed of cellobiohydrolases (CBHs) and endoglucanases (EGs). CBHs act on the crystalline regions of cellulose, releasing cellobiose from the end of cellulose chains, meanwhile EGs attack the amorphous regions (Chanzy et al. 1985). Most cellulases share a common structural organisation, with a catalytic domain (or core domain) connected to a cellulose-binding domain (CBD) via a linker peptide sensitive to proteolysis. The fungal CBDs are usually located at the $\mathrm{C}$ - or $\mathrm{N}$-terminus of the enzyme, and are about 30-40 amino acids long (Lenting \& Warmoeskerken 2001b).

It has been proposed that CBDs increase the effective enzyme concentration on the surface of the solid substrate, promoting the release of a single cellulose chain from the crystallite, by breaking hydrogen bonds (Tomme et al. 1995a; Linder \& Teeri 1997; Sridodusk et al. 1998). It has also been reported that CBDs have the ability to perform a nonhydrolytic disruption of cellulose fibres, releasing small particles (Din et al. 1991). Banka et al. (1998) demonstrated that a fibril-forming protein from Trichoderma reesei caused non-hydrolytic disruption of cotton fibres. Small fibrils were released, without detectable production of reducing sugars. Ida Lee et al. (2000) obtained images, by atomic force microscopy, of holes left in cotton fibres treated with hexachloropalladate-inactivated $\mathrm{CBH}$ I. The holes are believed to result from the penetration of the binding domain. In the same

Correspondence: Miguel Gama, Departamento de Engenharia Biológica, Universidade do Minho, Campus de Gualtar, 4710 Braga, Portugal. E-mail: fmgama@deb.uminho.pt 
study, a cellulase from Thermotoga maritime without a CBD was used, and no effect on the cotton fibres was detected. Recently, Irina Kataeva et al. (2002) detected modifications on the surface of the fibres, caused by the action of CBDs and fibronectin from C. thermocellum.

Lemos et al. (2002) developed a simple method to purify CBDs from fungal cellulases, following digestion with a protease. Using this process, it is possible to obtain gram amounts of CBDs, although with some contaminating enzymatic activity. In this work, we analysed whether fabrics treated with CBDs with very low hydrolytic activity-presented the same finishing quality as fabrics treated with cellulases.

\section{Materials and methods}

Enzymes

Cotton fabrics were treated with Cellulose-Binding Domains (CBDs) obtained from a cellulase preparation (Celluclast, Novozymes), and with several commercial enzymes (including Cellusoft APL, Novozymes, industrially used for depilling).

\section{CBD production}

Celluclast $(1.5 \mathrm{~L})$ was diluted to a total volume of $5 \mathrm{~L}$ with distilled water. To remove low molecular weight compounds, it was washed in a Pellicon 2 Ultrafiltration Module (Millipore), equipped with a 30-kDa nominal weight cut-off membrane, for about $12 \mathrm{~h}$, with sodium acetate buffer ( $25 \mathrm{mM}, \mathrm{pH} 5$ ).

Proteolysis was done with papain (papaya latex, Sigma). A concentration of $1 \mathrm{~g}$ papain $3000 \mathrm{~g}^{-1}$ protein was used, for $3 \mathrm{~h}$ at room temperature. The papain was previously activated with $\beta$-mercaptoethanol (concentration of $1 \times 10^{-4} \mathrm{~mL} \mathrm{~mL}^{-1}$ papain), for $15 \mathrm{~min}$ at room temperature. The protein concentration was measured using the BCA Protein Assay Kit (Pierce). After digestion, the mixture was filtered using an Ultrafiltration Module (Millipore), equipped with a $10-\mathrm{kDa}$ nominal weight cut-off membrane. CBDs were collected in the permeate. The CBDs were also further purified by ion-exchange chromatography, using a XK 50/60 column packed with DEAE Sepharose ${ }^{\text {TM }}$ Fast Flow, and a FLPC system from Pharmacia. The column was equilibrated with Phosphate buffer $\mathrm{pH}$ 7.5. CBDs (neutral peptides) were eluted at a flow rate of $3 \mathrm{~mL} \mathrm{~min}{ }^{-1}$, and separated from the charged peptides retained in the column. Fractions of $10 \mathrm{~mL}$ were collected and optical density at $280 \mathrm{~nm}$ was registered in a LKB Recorder REC 102, from Pharmacia.

\section{Depilling treatment of cotton fabrics}

The tests were performed in a Mathis, Drum Dyeing and Washing Unit (Type TWA $1.55 \mathrm{~kg}^{-1}$ ) and in a smaller machine, a Mathis Beaken Labomat (Type BFA). The fabric was a RIB $1 \times 1 \quad 100 \%$ Cotton. Two pre-treatments were carried out. In the first, called 'boiling', the fabric was treated with $0.5 \mathrm{~g} \mathrm{~L}^{-1}$ of Kieralon ED 835 (surfactant), $1 \mathrm{~g} \mathrm{~L}^{-1}$ of Lufibrol DK (extracting auxiliary for pre-treatment) and $2 \mathrm{~g} \mathrm{~L}^{-1}$ of caustic soda, for $30 \mathrm{~min}$ at $100^{\circ} \mathrm{C}$. In the other one, called ' $1 / 2$ white', the fabric was treated with $0.5 \mathrm{~g} \mathrm{~L}^{-1}$ of Kieralon ED 835, $0.5 \mathrm{~g} \mathrm{~L}^{-1}$ of Tinoclarite 4525 (peroxide stabilizer), $2 \mathrm{~g} \mathrm{~L}^{-1}$ of caustic soda $50 \%$ and $2 \mathrm{~g} \mathrm{~L}^{-1}$ of $\mathrm{H}_{2} \mathrm{O}_{2}$, for $25 \mathrm{~min}$ at $95^{\circ} \mathrm{C}$. Then, Baylase EFR (an enzyme used for the removal of residual peroxide) was added, for $10 \mathrm{~min}$, to remove the residual $\mathrm{H}_{2} \mathrm{O}_{2}$.

The depilling treatments were made in $30 \mathrm{~L}$ of water, with $2 \mathrm{~kg}$ of fabric, in the larger Mathis machine. The agitation rate was $25 \mathrm{rpm}$ for $45 \mathrm{~min}$, at $55^{\circ} \mathrm{C}$ and $\mathrm{pH} 5-5.5$, when using Cellusoft APL. The assays with CBDs were performed for $90 \mathrm{~min}$, at the same temperature. In the smaller machine, $200 \mathrm{~g}$ of fabric was treated in $3 \mathrm{~L}$ of water, at an agitation rate of $55 \mathrm{rpm}$ and temperature set to $55^{\circ} \mathrm{C}$. The reaction was terminated by adding $\mathrm{NaOH}$ to the mixture, to a final concentration of $0.5 \mathrm{~g} \mathrm{~L}^{-1}$, to remove the protein adsorbed to the fabric. Different concentrations of enzyme and CBDs were used.

\section{Analysis}

Hydrolytic activities of cellulases and CBDs preparations, expressed as Filter Paper Units (FPU), were determined as the amount of sugars released after one hr at $50^{\circ} \mathrm{C}$, using filter paper (Whatman $n^{\circ}$ 1) as insoluble substrate. Soluble sugars were measured using the dinitrosalicylic acid method (DNS), using glucose as standard (Miller 1959).

Supernatants analysis. The soluble sugars released during depilling were measured as described above (Miller 1959). The adsorption of protein was calculated as the difference between the concentrations before and after treatment.

Fabric analysis. Fabrics were characterized for the degree of pilling, weight and strength loss. Weight loss was determined as the difference in the fabric's weight before and after treatment.

The fabric resistance to tension was measured using the Truburst, Bursting Strength Tester (James H. Heal \& Co Ltd). Five tests were performed, and the difference between the reference and treated fabrics was calculated. 
The pilling tendency was measured using a $\mathrm{Nu}$ Martindale 404 Abrasion \& Pilling Tester (James H. Heal \& Co Ltd). The samples were rated from 0 to 5 according to the degree of pilling ( $\mathrm{K} 3$ value), by the experienced personnel from Vale de Tábuas.

Fabric samples were observed by electron microscopy (Leica, Cambridge S360). The samples were coated with gold particles in a Fisons Instruments Polaron SC502 Sputter Coater.

\section{Adsorption study of CBD-FITC conjugates on cotton fibres}

Adsorption tests were performed with $80 \mathrm{mg}$ of cotton and a CBD concentration of $70 \mu \mathrm{g} \mathrm{mL}^{-1}$. Sodium acetate buffer ( $50 \mathrm{mM}, \mathrm{pH}$ ) was added to a final volume of $4 \mathrm{~mL}$, and the CBDs were allowed to absorb for $90 \mathrm{~min}$, at $20^{\circ} \mathrm{C}$. Fluorescence microscocopy was performed in a Zeiss AxiosKop microscope. The images were acquired with a Zeiss AxioCam camera and analyzed with the AxioVision software. Details of the image analysis procedure and calibration are presented elsewhere (Amaral et al. 2005).

Fluorescein isothiocyanate (FITC) was obtained from Sigma. CBD-FITC conjugation was performed using the Sigma procedure. Briefly, FITC was mixed with a CBD solution $\left(20 \mu \mathrm{g}_{\text {FITC } \mathrm{mg}^{-1}}\right.$ CBD) using a protein concentration of $2 \mathrm{mg}$ protein $\mathrm{mL}^{-1}$ in $0.1 \mathrm{M}$ HEPES buffer, $\mathrm{pH}$ 9. This solution was incubated overnight in the dark, at room temperature, with magnetic stirring. To separate the unbound FITC, the labelled CBD mixture was passed through a BIO-GEL P-4 (BIO-RAD) column, previously equilibrated with $50 \mathrm{mM}$ sodium acetate buffer.

\section{Results and discussion}

\section{CBD production}

CBD production was carried out using a modification of the method described previously (Lemos et al. 2002) the cellulase was treated with papain, and the binding domains were separated by ultrafiltration. In these experiments, a UF Pellicon system from Millipore was used, allowing gram scale production of peptides. This preparation was found to have a residual catalytic activity (Figure 1) higher than that obtained in the smaller scale systems used in previous work (Lemos et al. 2002). Further purification of the binding domains was carried out by anion exchange chromatography. The FPU activity of the CBDs obtained, and also of several other commercial enzymes, is shown in Figure 1. As expected, the CBD preparations had a much lower activity than Cellusoft, a cellulase industrially used for depilling. The chromatography step further reduced the residual activity. Although still bearing some hydrolytic activity, this CBD sample was used to test the depilling effect of possible interfacial modifications associated to peptide adsorption. Besides Cellusoft and CBDs, other cellulolytic enzymes were tested in the depilling treatment, in an attempt to find a relationship between the depilling effect and the enzyme kind of activity. Both highly active formulations such as Bactonosol and partially purified proteins obtained from Trichoderma reesei recombinant strains, Primalco $\mathrm{G}$ and $\mathrm{H}$ (enzymes enriched in EG I and $\mathrm{CBH}$, respectively), were used.

MALDI and capillary electrophoresis analysis of the CBD sample revealed a main peptide of $8 \mathrm{kDa}$, and minor amounts of peptides of about $20 \mathrm{kDa}$ (Pinto et al. in press) which might contribute to the residual activity. Furthermore, amino acid sequence analysis revealed that the protein obtained was almost pure CBD from Trichoderma reesei $\mathrm{CBH}$ I. The sequence obtained by $\mathrm{N}$-terminal analysis, GNPPG, is present only in CBH I, between the catalytic domain and the linker. This indicates that the CBDs purified by Ion Exchange chromatography were rather pure, as discussed elsewhere (Pinto et al. in press). The residual activity is thus likely to

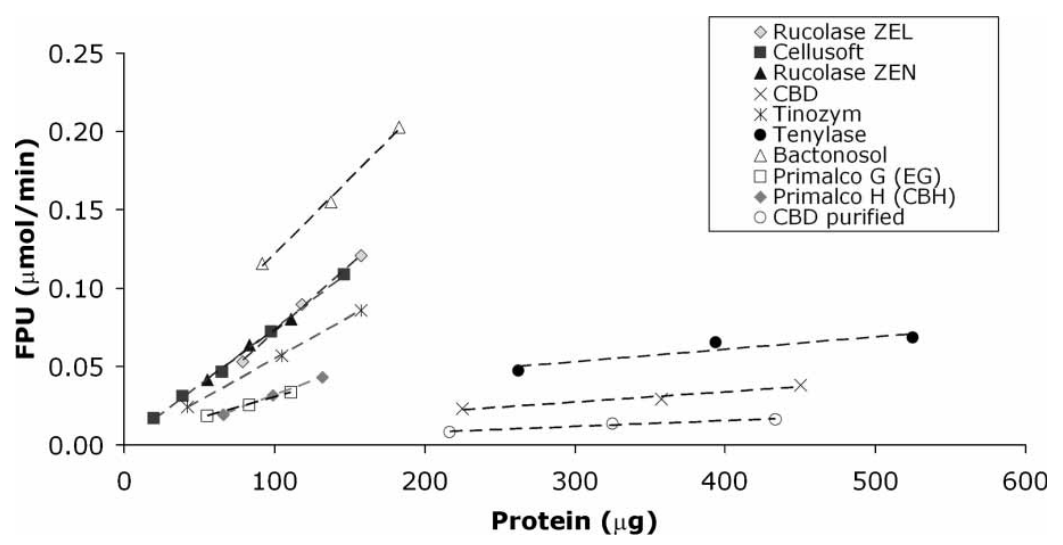

Figure 1. Enzymatic activity of several enzymes and CBD on filter paper. 
be associated with catalytic domains, present in low amounts, released during the papain digestion. It is generally accepted that these residual catalytic peptides (without binding modules) are unlikely to be active on the more crystalline cellulose.

\section{Depilling experiments}

Figure 2 shows images obtained by electron microscopy of the treated and non-treated fabrics. It is evident that both the enzymatic and CBD treatments mainly remove the loose fibres on the surface of the fabric. The fibres removed in the depilling process are apparently 1-2 $\mathrm{mm}$ long (Figure 2), being loosely bound to the woven fabric. Smaller fibres or fuzz are probably also removed.

The released soluble sugars, tensile strength loss, and the depilling effect were measured. The results obtained (both with the larger and the smaller machine), are shown in Table I. The sugars solubilised by enzymes and CBDs correspond respectively, to incubation periods of 45 and $90 \mathrm{~min}$. The larger machine has more effective and turbulent agitation than the smaller one. The mechanical treatment is of great importance for the effective finishing of the fabric. In fact, as can be seen in Table I, the degree of pilling obtained in the Mathis Labomat (small machine) was worse, for comparable enzyme concentrations. Compared to the hydrolytic activities detected in the filter paper assays, it appears that hydrolysis carried out by CBDs is enhanced by the mechanical action of the Mathis machines.

The depilling obtained with Cellusoft is dependent on the enzyme concentration. By lowering the protein dosage from 1.5 to 1.1 and $0.75 \mathrm{mg} \mathrm{g}^{-1}$, less effective depilling is observed ( $\mathrm{K} 3$ values of 5, 3.5 and 3, respectively). Interestingly, it was possible to obtain a similar depilling effect using the CBDs preparation. Although having a much lower hydrolytic specific activity, these peptides effectively remove fibrils from the fabric's surface. The results clearly show that it is possible to obtain the highest depilling effect, with a much lower sugar release than with Cellusoft. Lowering the sugar release is convenient, allowing a lower weight loss and reduction of the effluent treatment costs. For instance, sugar release up to a concentration of $0.7 \mathrm{~g} \mathrm{~L}^{-1}$ corresponds to a depilling class 4 using Cellusoft; the same classification was obtained using CBDs corresponding to a sugar release of only $0.20-0.28 \mathrm{~g} \mathrm{~L}^{-1}$. It appears that, with Cellusoft (45 min treatment, with protein concentration of $1-1.5 \mathrm{mg} \mathrm{g}^{-1}$ ), a sugar solubilisation approximately 2-fold higher than the one produced with CBDs (90 min treatment, with protein concentration of $3-4 \mathrm{mg} \mathrm{g}^{-1}$ ) is necessary for similar depilling to be obtained. It has been reported (Cavaco-Paulo et al. 2000) that catalytic domains alone can perform depilling, CBD being useless under very high levels of mechanical agitation, due to a synergy between mechanical agitation and hydrolytic activities. In this study, mechanical agitation was the same in all assays (for each machine), and CBDs produce much better results than cellulases with equivalent enzymatic activity (e.g. Cellusoft $0.75 \mathrm{mg} \mathrm{g}^{-1}$ versus CBD $3.5 \mathrm{mg} \mathrm{g}^{-1}$, see Table I). This may be due to the higher amount of protein adsorbed in the fibres, in the assays with binding modules.

The positive results obtained with CBDs raise intriguing questions about the depilling mechanism: why do peptides with a low specific activity perform well compared with commercial cellulases? In our view, two explanations may be advanced to answer this question: (1) the residual activity present in the CBD preparation matches the needs for the removal of pills, with no unnecessary release of soluble material; (2) the adsorbed binding modules, while having no catalytic activity, somehow affect the surface properties, leading to the desired effect. It has been shown in previous work, by using an Inverse Gas Chromatography technique, that CBDs modify the surface properties of cellulosic fibres (Pinto et al. 2004). In order to evaluate whether the removal of the trace hydrolytic activity would affect the depilling ability of CBDs, two further assays were carried out. The treatment of the fabric was conducted at room temperature $\left(25^{\circ} \mathrm{C}\right)$, and the $\mathrm{CBDs}$ purified by anionic
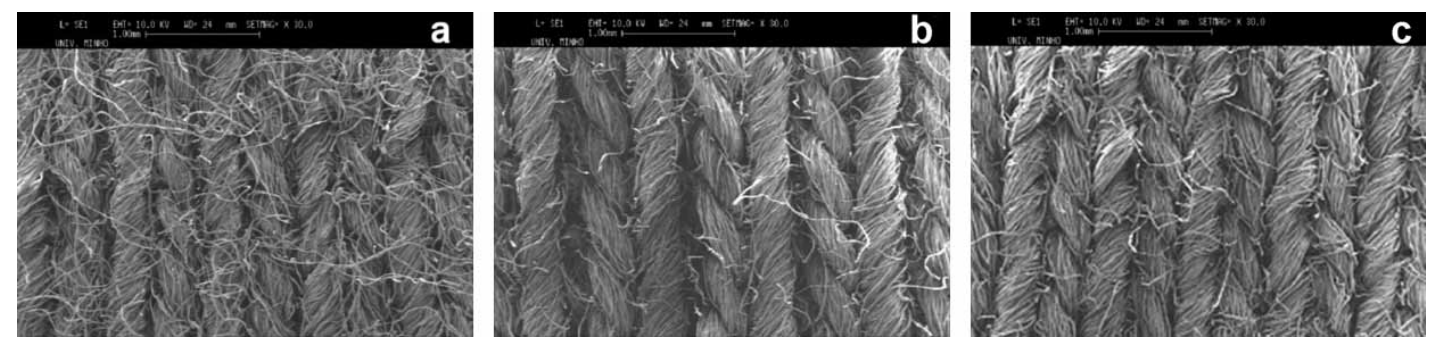

Figure 2. Non-treated fabric (a), enzyme treated fabric (b) and CBD treated fabric (c) observed by electronic microscopy at $30 \times$ magnification. 
Table I. Effect of CBDs and Cellusoft on the treatment of cotton fabrics. *

\begin{tabular}{|c|c|c|c|c|c|}
\hline CBD & $\begin{array}{l}\text { Soluble sugars } \\
\qquad\left(\mathrm{g} \mathrm{L}^{-1}\right)\end{array}$ & $\begin{array}{l}\text { Insoluble weight loss } \\
(\%)\end{array}$ & $\begin{array}{c}\text { Total weight loss } \\
(\%)\end{array}$ & $\begin{array}{c}\text { Strength loss } \\
(\%)\end{array}$ & $\begin{array}{c}\text { Pilling } \\
\text { degree (K3) }\end{array}$ \\
\hline Raw fabric & - & - & - & - & 2 \\
\hline $3 \mathrm{mg} \mathrm{g}^{-1}$ & 0.20 & 0.80 & 1.0 & 2 & 4 \\
\hline $3.5 \mathrm{mg} \mathrm{g}^{-1}$ & 0.28 & 2.22 & 2.5 & 9 & 4.5 \\
\hline $4 \mathrm{mg} \mathrm{g}^{-1}$ & 0.45 & 2.55 & 3.0 & 13 & 5 \\
\hline $25^{\circ} \mathrm{C}, 3.8 \mathrm{mg} \mathrm{g}^{-1}$ & 0.17 & 2.83 & 3.0 & 15 & 3.5 \\
\hline $1 / 2$ white, $4 \mathrm{mg} \mathrm{g}^{-1}$ & 0.34 & 1.66 & 2.0 & 12 & 4 \\
\hline CBDs purified (i.e.) & 0.00 & 2.0 & 2.0 & 15 & $2.5-3$ \\
\hline Labomat, $3.3 \mathrm{mg} \mathrm{g}^{-1}$ & 0.23 & n.d. & n.d. & 17 & $3.5-4$ \\
\hline Labomat, $5.8 \mathrm{mg} \mathrm{g}^{-1}$ & 0.21 & n.d. & n.d. & 17 & $4-4.5$ \\
\hline \multicolumn{6}{|l|}{ Cellusoft } \\
\hline $0.75 \mathrm{mg} \mathrm{g}^{-1}$ & 0.37 & n.d. & n.d. & n.d. & 3 \\
\hline $1.1 \mathrm{mg} \mathrm{g}^{-1}$ & 0.40 & n.d. & n.d. & n.d. & 3.5 \\
\hline $1.12 \mathrm{mg} \mathrm{g}^{-1}$ & 0.68 & 3.42 & 4.1 & 15 & 4 \\
\hline $1.2 \mathrm{mg} \mathrm{g}^{-1}$ & 0.70 & 3.90 & 4.6 & 18 & 4 \\
\hline $1.5 \mathrm{mg} \mathrm{g}^{-1}$ & 0.88 & 5.02 & 5.9 & 15 & 5 \\
\hline $1 / 2$ white, $1.5 \mathrm{mg} \mathrm{g}^{-1}$ & 0.90 & 3.00 & 3.9 & 12 & 4 \\
\hline Labomat, $2.6 \mathrm{mg} \mathrm{g}^{-1}$ & 0.49 & n.d. & n.d. & 14 & $4-4.5$ \\
\hline Labomat, $3.9 \mathrm{mg} \mathrm{g}^{-1}$ & 0.54 & n.d. & n.d. & 21 & $4-4.5$ \\
\hline
\end{tabular}

* Except when otherwise stated, all assays where conducted at $50^{\circ} \mathrm{C}$, in the larger MATHIS machine, with the RIB fabric. The protein concentration used in each assay (either CBD or enzyme) is shown. n.d. - not determined; i.e. ion exchange.

chromatography were used. In both cases (Table I), the catalytic activity was much lower or negligible, and the depilling effect was substantially reduced. It is thus apparent that the hydrolytic activity associated with the CBD preparation is necessary. However, in our view, this does not rule out the second hypothesis above suggested. Interfacial modification may be also a part of the depilling mechanism, as will be further discussed.

The depilling process, carried out at industrial scale, is not always a predictable process. The treatment time, and the enzymatic load needed for the final desired properties, may vary significantly. Being produced by a complex cooperative effect of enzyme activity and mechanical stress, depilling depends on the characteristics of the fabric, fibrillation, surface properties and amorphous character of the fibres. A significant loss of tensile strength arises while using enzymes. This is considered the major limitation for a more widespread use of this technology. The development of a process, involving lower risk in this regard, seems highly desirable. We analyzed the effect of successive CBD treatments, to verify whether the reduced sugar release would lead to better control of the fabric's tensile strength. As can be seen from data on Table II, successive treatments were performed in order to observe the tensile strength loss with Cellusoft and CBDs. Tests were performed on jersey+lycra and on $100 \%$ cotton fabrics.

There was no significant difference between the use of Cellusoft and CBDs. In fact, for all these successive treatments, the tensile strength loss was very similar, regardless of whether CBDs or Cellusoft were used. A number of possible explanations are available:

1. removal of the loose fibres on the surface of the fabric may be responsible for the loss of the tensile strength

Table II. Effect of successive treatment of fabrics using Cellusoft and CBD.

\begin{tabular}{lccc}
\hline Fabric & Control & Cellusoft & CBD \\
\hline Jersey + Lycra & & & \\
1st treatment & & & \\
Pressure (kPa) & 460 & 378 & 380 \\
Strength loss & - & $21 \%$ & $18.7 \%$ \\
2nd treatment & & & \\
$\quad$ Pressure (kPa) & 460 & 379 & 375 \\
Strength loss & - & $21.1 \%$ & $24.4 \%$ \\
3rd treatment & & & \\
Pressure (kPa) & 480 & 352 & 357 \\
Strength loss & - & $26.8 \%$ & $25.5 \%$ \\
100\% RIB Cotton & & & \\
1st treatment & & & \\
Pressure (kPa) & 776 & 622 & 651 \\
Strength loss & - & $19.9 \%$ & $16.2 \%$ \\
2nd treatment & & & \\
Pressure (kPa) & 776 & 661 & 648 \\
Strength loss & - & $14.4 \%$ & $16.6 \%$ \\
3rd treatment & & & \\
Pressure (kPa) & 762 & 559 & 584 \\
Strength loss & - & $26.7 \%$ & $23.3 \%$ \\
\hline
\end{tabular}


2. the adsorption of the proteins may modify the cellulose structure, by breaking hydrogen bonds (Tomme et al. 1995; Linder and Teeri, 1997; Sridodusk et al. 1998) or by nonhydrolytic disruption (Din et al. 1991)

3. a very low hydrolysis rate may suffice to affect the mechanical properties of cotton fabrics.

Other enzymes in varying amounts were also used in depilling experiments (Table III). A concentration effect is clearly evident in depilling effectiveness. As previously observed for the Cellusoft assays, there is no obvious trend relating the sugar release and the effect in tensile strength. Interestingly, the enzymes Primalco $\mathrm{G}$ and $\mathrm{H}$, which have mainly endoglucanase and exoglucanase activities, respectively, produced rather distinct effects. Whilst releasing similar amounts of sugar, and reducing tensile strength to a similar extent, the endoglucanase is much more effective in depilling. This agrees with the results of Heikinheimo et al. (1998) who found that endoglucanases are more effective in the depilling of twill and poplin fabrics, as now observed in this work with RIB fabric. Figure 1 shows that Primalco G and H were the least active enzymes among the ones tested, probably due to the fact that they are relatively pure, and hence, due to lack of synergy, have a low hydrolysis rate. The performance of Primalco G and CBDs is comparable, with regard to the depilling effect versus sugar release and tensile loss. The other enzymes were all less effective, taking these criteria together. Celluclast, Bactonosol, Tynozime, Rucolase ZEL, Rucolase ZEN, all perform well in removing pills, but always at the expense of higher sugar release or tensile loss, as compared to the more effective CBD preparation and Primalco G.

\section{Adsorption study of CBD-FITC conjugates on cotton fibres}

Cotton fibres were treated with CBD-FITC conjugates and observed by optical microscopy. The FITC is conjugated with the protein through the free amines of the CBD. Since the CBD produced in this work has only one amine in the terminal region, the FITC should not affect the binding properties. Indeed, it has been demonstrated by measuring binding isotherms of CBDs, that the FITC does not affect the binding properties (Jervis et al. 1997). The distribution of the binding domains adsorbed on cotton was observed, and an estimation of the 'fibre covered fraction' was attempted. The CBD concentration was equivalent to that used in the depilling tests $\left(3.5 \mathrm{mg}_{\mathrm{CBD}} \mathrm{g}_{\text {cotton }}\right)$. Figure 3 shows images of the cotton fibres treated for $90 \mathrm{~min}$ at $20^{\circ} \mathrm{C}$.

The concentration of CBDs was calculated at several points (shown by arrows) using a calibration of fluorescence intensity versus CBD concentration (Amaral et al. 2005). Considering the superficial area of a single CBD as equal to $5.4 \mathrm{~nm}^{2}$ (Tomme et al. 1995b), the theoretical surface molar concentration corresponding to a monolayer is $3.08 \times$ $10^{-13} \mathrm{~mol}_{\mathrm{CBD}} / \mathrm{mm}^{2}$. The calculated concentrations are comprised between $7.93 \times 10^{-13}$ and $20.87 \times$ $10^{-13} \mathrm{~mol}_{\mathrm{CBD}} / \mathrm{mm}^{2}$, with an average value of $15 \times$ $10^{-13} \mathrm{~mol}_{\mathrm{CBD}} / \mathrm{mm}^{2}$. These results clearly demonstrate that the surface of the fibres is largely covered with binding domains. In fact, the concentration of

Table III. Effect of several enzymes on the treatment of RIB fabric.

\begin{tabular}{|c|c|c|c|c|c|}
\hline Enzyme & $\begin{array}{l}\text { Enzyme concentration } \\
\qquad\left(\mathrm{g} \mathrm{L}^{-1}\right)\end{array}$ & $\begin{array}{l}\text { Soluble sugars } \\
\qquad\left(\mathrm{g} \mathrm{L}^{-1}\right)\end{array}$ & $\begin{array}{l}\text { Weight loss } \\
(\%)\end{array}$ & $\begin{array}{l}\text { Strength loss } \\
(\%)\end{array}$ & $\begin{array}{c}\text { Pilling } \\
\text { degree (K3) }\end{array}$ \\
\hline Bactonosol & $\begin{array}{l}0.67 \\
0.20\end{array}$ & $\begin{array}{l}0.41 \\
0.22\end{array}$ & $\begin{array}{l}1.96 \\
2.50\end{array}$ & $\begin{array}{l}14 \\
16\end{array}$ & $\begin{array}{l}4 \\
3\end{array}$ \\
\hline Primalco $\mathrm{H}$ & $\begin{array}{l}6.70 \\
2.33 \\
5.00\end{array}$ & $\begin{array}{l}0.34 \\
0.14 \\
0.32\end{array}$ & $\begin{array}{l}3.00 \\
1.51 \\
2.00\end{array}$ & $\begin{array}{r}19 \\
8 \\
13\end{array}$ & $\begin{array}{l}2 \\
2 \\
2\end{array}$ \\
\hline Primalco G & $\begin{array}{l}6.70 \\
2.33 \\
6.00\end{array}$ & $\begin{array}{l}0.34 \\
0.17 \\
0.29\end{array}$ & $\begin{array}{l}2.58 \\
1.59 \\
1.00\end{array}$ & $\begin{array}{r}11 \\
7 \\
9\end{array}$ & $\begin{array}{l}4.5 \\
3 \\
4\end{array}$ \\
\hline Celluclast & $\begin{array}{l}1.17 \\
0.33\end{array}$ & $\begin{array}{l}0.68 \\
0.27\end{array}$ & $\begin{array}{l}4.19 \\
5.35\end{array}$ & $\begin{array}{r}20 \\
8\end{array}$ & $\begin{array}{l}4.5 \\
3\end{array}$ \\
\hline Rucolase ZEL & $\begin{array}{l}1.33 \\
0.67\end{array}$ & $\begin{array}{l}0.90 \\
0.58\end{array}$ & $\begin{array}{l}4.20 \\
3.50\end{array}$ & $\begin{array}{l}17 \\
13\end{array}$ & $\begin{array}{l}4.5-5 \\
4.5-5\end{array}$ \\
\hline Rucolase ZEN & $\begin{array}{l}3.33 \\
1.67\end{array}$ & $\begin{array}{l}0.69 \\
0.47\end{array}$ & $\begin{array}{l}4.20 \\
2.52\end{array}$ & $\begin{array}{r}9 \\
12\end{array}$ & $\begin{array}{l}4.5-5 \\
4.0-4.5\end{array}$ \\
\hline Tynozim & $\begin{array}{l}1.00 \\
0.33\end{array}$ & $\begin{array}{l}0.37 \\
0.21\end{array}$ & $\begin{array}{l}4.35 \\
2.46\end{array}$ & $\begin{array}{l}10 \\
18\end{array}$ & $\begin{array}{l}4.0-4.5 \\
3.0-3.5\end{array}$ \\
\hline
\end{tabular}




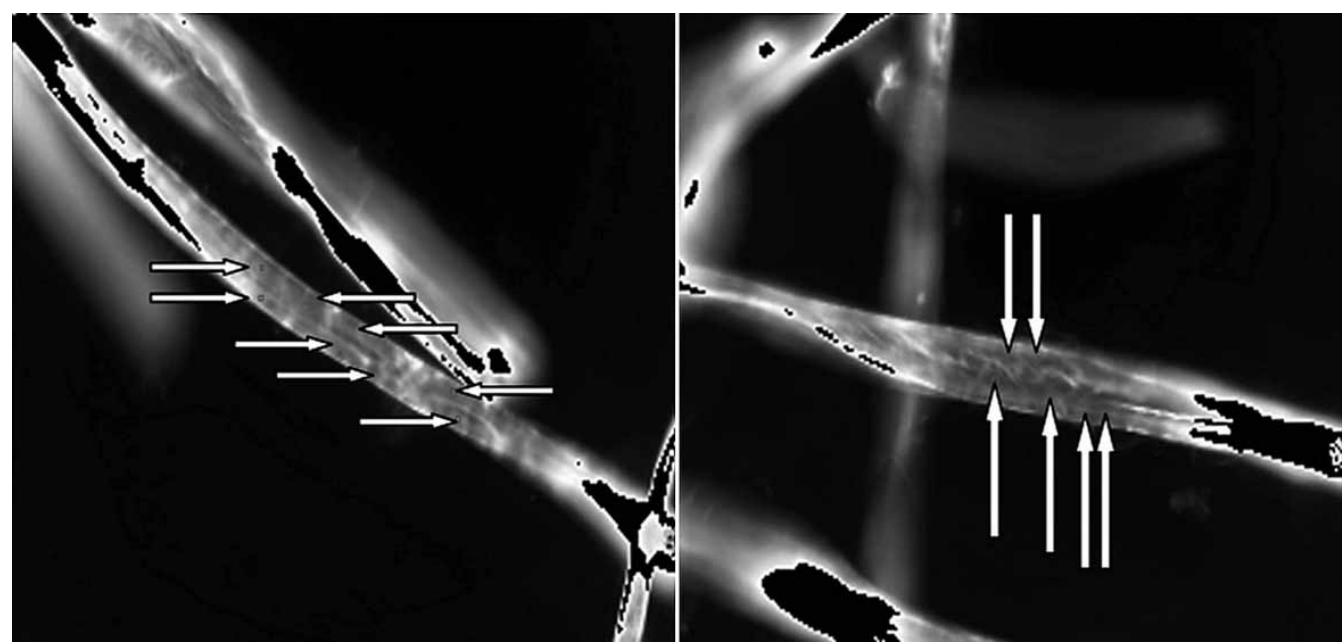

Figure 3. Cotton fibres treated with FITC-CBD conjugates $\left(70 \mu \mathrm{g} \mathrm{mL}{ }^{-1}\right)$ for $90 \mathrm{~min}$ at $20^{\circ} \mathrm{C}$, observed by optical microscopy. The arrows show the spots used to estimate - by image analysis - the surface concentration of CBDs. The black regions, in the surface of the fibres, are out of range in the calibration used to estimate the surface concentration [14].

CBD per $\mathrm{mm}^{2}$ on the fibres is larger than the theoretical value for two layers of CBDs covering the fibre (considering both sides of the fibre, since it was observed that fluorescent emission crosses the fibre without reduction in intensity). The model of fibres as two flat layers obviously does not correspond to the real fibres, which are threedimensional structures. This may account for the estimated fraction of surface coverage being over the theoretical maximum value (monolayer). Nevertheless, it is clear that the concentration of CBD on the surface, is very high. These studies are described elsewhere in more detail (Amaral et al. 2005).

\section{Conclusions}

The following conclusions may be drawn from the depilling experiments:

1. it is not possible to simply relate the extent of hydrolysis with the depilling effect and tensile strength loss. On the other hand, the type of activity seems to be important, the endoglucanases being more effective, as has been pointed out by other authors

2. Among the formulations tested in this work, the CBD preparation is the most effective; however, the depilling effect cannot be attributed solely to an effect associated with the binding modules alone. Indeed, using CBDs at room temperature (lowering the residual catalytic activity), or using CBDs purified by anionic chromatography, resulted in a poorer depilling effect. Thus, the adsorption of the binding domains alone is not sufficient for the removal of the fuzz, small fibres, or loosely bound fibres.

3. Based on the results obtained with the successive treatments, it appears that total elimination of the tensile strength loss cannot be avoided, even by substantially reducing the release of sugars.

The results with CBD-FITC conjugates demonstrate that the surface concentration of CBDs adsorbed to cotton fibres is very high. Considering these results, it seems obvious that interfacial properties should be considered in the depilling treatments.

\section{References}

Amaral AL, Pinto R, Carvalho J, Ferreira EC, Gama FM. 2005. Determination of CBD-FITC concentration on fibres, Sinaferm 2005, 2-5 August, Recife, Pernambuco, Brasil.

Banka RR, Mishra S, Ghose TK. 1998. Fibril formation from cellulose by a novel protein from Trichoderma reese $i$ : A nonhydrolytic cellulolytic component? World J Microbiol Biotechnol 14:551-558.

Cavaco-Paulo A, Azevedo H, Bishop D. 2000. Effects of agitation on the adsorption, desorption, and activities on cotton fabrics of full length and core domains of EGV (Humicola insolens) and CenA (Cellulomonas fimi). Enzym Microb Technol 27:325329.

Chanzy H, Henrissat B. 1985. Undirectional degradation of valonia cellulose microcrystals subjected to cellulase action. FEBS Lett 184:285-288.

Din N, Gilkes RN, Tekant B, Miler RC, Warren RAJ, Kilburn DG. 1991. Non-hydrolytic disruption of cellulose fibres by the binding domain of a bacterial cellulase. Bio/Technol 9:10961099.

Heikinheimo L, Cavaco-Paulo A, Pertti N, Siika-aho M, Buchert J. 1998. Treatments of cotton fabrics with purified Trichoderma reesei cellulases. J SDC 114:216-220. 


\section{R. Ramos et al.}

Jervis E, Haynes C, Kilburn D. 1997. Surface diffusion of cellulases and their isolated binding domains on cellulose. J Biol Chem 272:24016-24023.

Kataeva IA, Seidel III RD, Shah A, West LT, Li Xin-Liang, Ljungdahl LG. 2002. The Fibronectin Type 3-Like Repeat from the Clostridium thermocellum cellobiohydrolase CbhA promotes hydrolysis of cellulose by modifying its surface. Appl Environ Microbiol p. 4292-4300.

Lee I, Evans BR, Woodward J. 2000. The mechanism of cellulase action on cotton fibres: evidence from atomic force microscopy. Ultramicroscopy 82:213-221.

Lemos MA, Teixeira JA, Mota M, Gama FM. 2002. A simple method to separate cellulose-binding domains of fungal cellulases after digestion by a protease. Biotechnol Lett 22:703707.

Lenting HBM, Warmoeskerken MMCG. 2001a. Guidelines to come to minimized tensile strength loss upon cellulose application. J Biotechnol 89:227-232.

Lenting HBM, Warmoeskerken MMCG. 2001b. Mechanism of interaction between cellulase action and applied shear force, an hypothesis. J Biotechnol 89:217-226.
Linder M, Teeri TT. 1997. The roles and function of cellulosebinding domains. J Biotechnol 57:15-28.

Miller GL. 1959. Use of Dinitrosalicylic Acid reagent for determination of reducing sugars. Anal Chem 31:426-428.

Pinto R, Moreira S, Mota M, Gama M. 2004. Studies on the Cellulose-Binding Domains Adsorption to Cellulose. Langmuir 20:1409-1413.

Pinto R, Carvalho J, Mota M, Gama, FM. Large scale production of cellulose binding domains. Adsorption studies using CBDFITC conjugates. Cellulose, in press

Sridodusk M, Kleman-Leyer K, Keränen S, Kirk TK, Teeri TT. 1998. Modes of action on cotton and bacterial cellulose of a homologous endoglucanase-exoglucanase pair from Trichoderma reesei. Eur J Biochem 251:885-892.

Tomme P, Warren RAJ, Gilkes NR. 1995a. Cellulose hydrolysis by bacteria and fungi. Adv Microbiol Physiol 37:1-81.

Tomme P, Diane P, Driver DP, Amandoron EA, Miller RC, Antony R, Warren J, Kilburn DG. 1995b. Comparison of a Fungal (Family I) and Bacterial (Family II) Cellulose-Binding Domain. J Bacteriol 177:4356-4363. 